\title{
Vijesti o španjolskoj gripi u puljskom dnevniku Hrvatski list
}

\author{
Izvorni znanstveni rad \\ Original scientific paper
}

UDK 616.921.5-036.22(497.5 Pula):070“1918“

Hrvatski list koji je kao dnevnik na hrvatskom jeziku u Puli izlazio od 1. srpnja 1915. do 18. prosinca 1918., između ostalih vijesti sredinom i u drugoj polovici 1918. donosi izvješća o španjolskoj gripi. Sporadični članci pišu o pojavi i kretanju španjolske gripe u Europi, broju oboljelih u određenim europskim gradovima, pojavi gripe u Puli, značajkama same bolesti, preporučenim mjerama zaštite, zatvaranju škola zbog zaraze te objavljuje osmrtnice stradalih od španjolske gripe. Putem analize objavljenih članaka dolazi se između ostaloga do odgovora koliko je španjolska gripa zastupljena u listu u odnosu na druge teme, kakav je bio odnos stanovnika prema novoj bolesti, kakvo je bilo znanje o profilaksi i liječenju gripe, jesu li članci u Hrvatskom listu pandemiju prikazivali na sličan način kao i listovi u sjevernoj Hrvatskoj i je li valna distribucija gripe koja je na području Hrvatske primjetna, istovremeno zorno popraćena i u puljskom listu.

Ključne riječi: španjolska gripa, vijesti, Hrvatski list, mortalitet, morbiditet, drugi val, „mentalitet zaborava“

\section{Uvod}

Dandemija španjolske gripe 1918.-1919. tek je tijekom posljednjih nekoliko desetljeća privukla pažnju povjesničara. Djela nastala netom nakon njena zbivanja bila su uglavnom medicinskoga karaktera i u njima se u prvom redu nastojala obrazložiti etiologija i patologija gripe kako bi se spremnije dočekala njena moguća ponovna pojava. Dugogodišnje historiografsko zatišje o španjolskoj gripi objasnilo se između ostaloga zasjenjenošću pandemije posljednjim operacijama Prvoga svjetskog rata, kratkim vijekom bolesti, nemogućnošću određivanja točnoga broja smrtnih žrtava, izostankom ugledne obitelji koja je podlegla bolesti te neuspjehom medicine $u$ borbi protiv nje - što ju je činilo neatraktivnom temom historiografskog istraživanja (Phillips et al. 2003: 2). Tome se može pridodati i nedostatak povijesnih izvora o pojavi, tijeku i posljedicama bolesti, u prvom redu kod zemalja zahvaćenih ratom u kojima se statistika oboljelih i umrlih nije sustavno vodila, a mjere javnoga zdravstva nisu poznate; zatim nedovoljna smionost povjesničara da zadiru u nezaobilaznu temu medicine, s obzirom na specifičan odnos povijesti i medicine u kojem je medicina do 1960-ih štovala nepisano pravilo da se samo liječnici trebaju baviti poviješću medicine jer ostali, bez medicinske naobrazbe i iskustva, ne razumiju sadržaj i nijanse polja (Rosenberg 1992: 2) ${ }^{1}$;

Argument kojim su branili ovu tvrdnju bio je da se empatija, etika i kognitivno razumijevanje koji su za pristup određenoj medicinskoj temi potrebni, mogu steći jedino putem kliničke prakse. Mješavina opreza i skepticizma 
te naposljetku i društveni stav prema španjolskoj gripi, tzv. "mentalitet zaborava“, koji se temelji na određenim filozofskim teorijama ${ }^{2}$ a objašnjava da se preživljene pošasti nastoje čim prije zaboraviti te u tom smislu nisu tema o kojoj se želi pisati (Crosby 2003: 282-290). ${ }^{3}$

Iznimno razorna i isto tako brza pandemija ${ }^{4}$ privlačnom će za povjesničare postati 1960ih, kad počinje veća produkcija historiografskih radova s tematikom španjolske gripe, a od 1970-ih zanimanje s akcelerirajućim kretanjem traje do današnjih dana. Razlog tome može biti novi polet historiografije tijekom posljednja tri desetljeća dvadesetoga stoljeća, kada je zanat povjesničara obogaćen novim metodološkim paradigmama, novim epistemološkim pristupima, novom arhivskom sirovinom, tehnički gotovo savršenim istraživačkim alatima i bezgraničnom tematikom (Bertoša 2002: 7), u što se tema španjolske gripe svojom osebujnošću vrlo lako uklopila; zatim nova medicinska saznanja o patologiji španjolske gripe koja su kulminirala 2005. rekonstrukcijom virusa A (H1N1) iz pluća dobro očuvanog tijela žrtve iz 1918., a koja su riješila određene dugogodišnje medicinske nedoumice i otvorila vrata novim saznanjima iz demografije, sociologije, povijesti i drugih znanosti; te naposljetku, novi pogled na poznate povijesne izvore iz 1918. i 1919., gdje se posebna pozornost dala tisku. $U$ tom je smislu iscrpljena politička i diplomatska povijest Prvoga svjetskog rata prepustila mjesto socijalnoj, kulturnoj, demografskoj, urbanoj i ekonomskoj povijesti, čime se upotpunila i još se uvijek upotpunjava slika dramatične svakodnevice ratne zbilje i poraća te istražuju one pojave koje su prvotnoj istraživačkoj ideji promakle.

S pokretačkom idejom da historiografija postavlja uvijek nova pitanja i uvijek daje nove odgovore (Bertoša 2002: 7) u ovom će se radu analitički pregledati članci u puljskom listu Hrvatski list koji donose vijesti o španjolskoj gripi, da bi se pokušalo odgovoriti na ova pitanja: je li pandemija gripe bila česta tema novinskih vijesti u Hrvatskom listu, jesu li je vijesti o ratnim događajima uspjele zasjeniti, kakav je bio odnos stanovnika prema novoj bolesti, kakav je općenito bio stav stanovnika Puljštine o pošastima u specifičnom razdoblju konačnog završetka ratne psihoze i početka novog ali nesigurnog života, potom kakvo je bilo znanje o profilaksi i liječenju gripe i jesu li članci u Hrvatskom listu pandemiju prikazivali na sličan način kao i u već analiziranim zagrebačkim listovima Hrvatska riječ, Hrvatska država i Obzor.

\section{Hrvatski list kao povijesni izvor}

Jedini dnevni list koji se u Puli u vrijeme pojave španjolske gripe tiskao na hrvatskom

obeshrabrivala je nemedicinske znanstvenike u istraživanju tema ovoga posebnog područja, te je do 1960-ih povijest medicine u prvom redu pisana od strane liječnika i za liječnike (Rosenberg 1992: 2).

2 U prvom redu misli se na teoriju njemačkog filozofa i sociologa Waltera Benjamina po kojoj je najvažniji element razvitka osobe i društva općenito upravo sposobnost sjećanja da iza sebe ostavi ruševine prošlosti (Crosby 2003: 282-283).

3 Liječnici nisu zdušno pristupili stvaranju "spomenika gripi“, jer bi on simbolizirao njihovu sramotu i nemoć znanstveno-medicinske zajednice u kojoj je dominirala bakteriologija, s obzirom na to da se prema još neotkrivenom virusu gripe nisu znali postaviti. Političari se također nisu htjeli sjećati epidemije, jer se njome nije mogao promovirati nikakav politički uspjeh u određenoj zajednici. Ovi su stavovi pridonijeli „mentalitetu zaborava“, kako ga naziva Crosby, pod time podrazumijevajući da se većina djelatnika medicinske struke zajedno s političarima i vladinim javnim zdravstvenim organizacijama nadala da usmeno svjedočanstvo neće dugo živjeti u pismenom društvu (Crosby 2003: 282-290). Primjer je sličnoga društvenog stava vidljiv i stotinjak godina ranije u Velikoj Britaniji, kad je 1832. završila epidemija kolere. Preživjeli su je pokušavali zaboraviti na način da se o njoj ne raspravlja. Čak se i članci s tematikom kolere u stručnim časopisima (poput Edinburgh Medical and Surgical Journal) neko vrijeme nisu objavljivali (Kolata 1999: 45).

$4 \quad$ Recentnija istraživanja procjenjuju da ukupni broj smrtnih žrtava od španjolske gripe 1918. i 1919. iznosi 50 milijuna ( $2,8 \%$ tadašnje svjetske populacije), s napomenom da ovaj broj može biti niži od stvarnoga broja smrtnih žrtava za ukupno 100\% (Johnson et al. 2002: 105-115). Većina će žrtava podleći gripi u njenom drugom valu, koji je u samo četiri mjeseca obišao svijet. 
jeziku, Hrvatski list, na dvije je stranice ili povremeno četiri ${ }^{5}$ stanovnike Puljštine obavještavao o političkim, socijalnim, gospodarskim događajima, zdravstvenim, prosvjetnim i kulturnim prilikama na svjetskoj i lokalnoj razini te ih katkad zabavnim štivom didaktičnog karaktera „prosvjećivao“. List se tiskao od 1. srpnja 1915., nakon obustave lista Naša sloga, do 18. prosinca 1918. kada je zabranjen od strane talijanske vlasti. Osam dana, od 30. ožujka do 6. travnja 1918. prinudno je policijski zaustavljen. Prvi broj izašao je u 300 primjeraka, a 1918. list je tiskan u 1700 do 3000 primjeraka. Članke su uređivali Josip Krmpotić, Mario Krmpotić, Fran Barbalić, Frane Bakarčić i ostali, a od 1917. kao novinar u listu djeluje i Mate Balota. Pored vijesti o stanjima na bojištima, novim političkim odlukama, pitanjima o sudbini Istre, pitanjima školstva u Istri, hrvatskoga jezika, problemu gladi i siromaštva, poglavito djece, pored objava o dijeljenju hrane, oglasa o pojedinim proizvodima i uslugama, kratkih didaktičkih priča o problemima u kojima se našao mali istarski čovjek (prostitucije, opijanja, lopovluka, odavanja djece cigaretama i alkoholu, i sličnih), te raznih oglasa i reklama, sredinom i u drugoj polovici 1918. protkali su se članci o pojavi i kretanju španjolske gripe, preporučenim mjerama zaštite, zatvaranju škola zbog gripe i ostali te tematike.

Španjolska se gripa na Puljštini javila u vrijeme kad su novine u Austro-Ugarskoj Monarhiji bile podvrgnute ratnoj cenzuri. Već je 1914. za civilne vlasti osnovan Ratni nadzorni ured za štampu koji je novinama davao upute o svemu što se moglo ili nije smjelo pisati i bio je pod kontrolom vrhovne vojne komande. Taj je položaj informativnog tiska uvjetovao da su listovi tiskali već objavljene članke iz raznih bečkih i peštanskih novina koje su bile prošle vojnu cenzuru. Cenzura je značila zabranu pisanja o Austro-Ugarskoj banci i nesigurnosti uloga, o skupoći, nestašici živežnih namirnica ili „uznemirujuće burzovne ili tržišne vijesti“ (Novak 2006: 96-97). Mate Balota, koji je u listu pisao 1917. i 1918. posvjedočio je da djelatnici Hrvatskog lista barem jednom tjedno dobivaju povjerljive direktive o tome što se smije a što ne smije pisati; jedna od direktiva bila je da se ne smije pisati o gladi, suši, mrazu i slabom funkcioniranju aprovizacije.

lako je cenzura vjerojatno donekle uvjetovala javljanje o španjolskoj gripi u tisku (zbog cenzure španjolska je gripa i dobila svoje ime!) tisak prikazuje sliku društva u svom vremenu te kao povijesni izvor „ne boluje od naknadne pameti, dio je povijesti svoga vremena i njegova identiteta" (Duda 2010: 14), a na povjesničaru je da pokuša istražiti značenje spomenutih, ali i izostavljenih informacija u novinskim člancima.

\section{Spomen španjolske gripe u Hrvatskom listu}

Španjolska se gripa u Hrvatskom listu prvi put spominje 4. lipnja 1918., gdje u članku pod naslovom „Epidemija u Španjolskoj“ piše: „U Španjolskoj je buknula neka zarazna bolest, za koju se ne zna, kakve je vrsti. Sada javljaju Lyonske novine, da se zaraza sve više širi. U Madridu je oboljelo 120.000 ljudi. Zaraza prelazi takodjer na životinje. Takodjer iz pokrajine se javlja, da se ta bolest širi“ (HL, 4. 6. 1918: 2). ${ }^{6}$ Vijest je samo nekoliko dana kasnila za prvom objavom u sjevernoj Hrvatskoj, kada je o „nepoznatoj bolesti“ pisao zagrebački list Hrvatska riječ. ${ }^{7}$ Članak će u puljskom Hrvatskom listu slijediti iza članaka "Zračna navala na Pariz" i "Novi tonažni ugovor između Švedske i Engleske“, a prethoditi člancima "Clemenceau u opasnosti da bude zarobljen“ i „Podmorski prodor kod Gibraltara“, čime se u kontekstu ovih političkih i vojnih događaja uviđa važnost pojave nove bolesti.

Utorkom i četvrtkom list se tiskao na četiri stranice, no nakon korjenitih političkih promjena u studenome 1918. i svoje upitne sudbine, list se na 4 stranice sporadično tiskao.

Navođenje iz lista obilježavat će se kraticom $H L$, datumom objave i stranicom.

U listu Hrvatska riječ vijest je o španjolskoj gripi objavljena 29. svibnja 1918. (Hutinec 2006: 228). 
Samo nekoliko dana kasnije, list u članku „Influenca u Španjolskoj“ obavještava da se „influenca u Španjolskoj sve više širi. Tečajem zadnjih četiriju dana poskočio je broj oboljelih u Madridu od 125.000 na 200.000. Broj umrlih povisio se od 39 na 100“ (HL, 8. 6. 1918: 1), nakon čega nema spomena o gripi sve do početka srpnja 1918. Čak i kad se u članku koji je objavljen krajem lipnja spominju bolesti u Dalmaciji, izostaje spomen španjolske gripe. Nije poznato je li to bilo zato što se ona ondje još nije pojavila ili jednostavno nije prepoznata. Spominju se boginje, trbušni tifus i malarija koji su se javili u pojedinim dalmatinskim selima (HL, 30.6. 1918: 4).

Dana 3. srpnja, među udarnim političkim vijestima, nalazi se i članak „Španjolska bolest" u kojem piše: „Novine javljaju, da se pojavilo mnogo slučajeva španjolske bolesti (neke vrsti influence) u Nürnbergu, Beču i u Budimpešti. U Monakovom ${ }^{8}$ može se, kako javlja Vossische Zeitung, govoriti već o pandemiji. Bolest se veoma brzo širi“ (HL, 3. 7. 1918: 1).

Nakon toga više od dva mjeseca izostaju vijesti o španjolskoj gripi, da bi se 20. rujna vratile preporučujući kako se od bolesti liječiti. U članku pod naslovom „Lek ${ }^{9}$ protiv španjolske groznice“ piše: „U lečničkom listu 'Wiener klinische Wochenschrift' priopćuje lečnik dr. Marković, da mu je uspelo pronaći lek, kojim se španjolska influenca dade izlečiti za 24 sata u svakom slučaju. To se postizava time, ako se bolesniku smesta nakon nastupa vrućine dade doza kalomela (0.3 do 0.6 grama), a svako 4-5 sati iza toga pol grama aspirina pomiješano $\mathrm{s}$ jednim decigramom koffeina. Bolesnici, koji tako rukovode, svi bez iznimke gube vrućinu i reše se svake komplikacije (...)" (HL, 20. 9. 1918: 2). lako se u nastavku savjetuje opreznost pri uzimanju kalomela koji je opasna živina sol, ovo je izrazito spekulativna i opasna mjera protiv simptoma gripe. Ovo je jedini članak o "lijeku“ protiv gripe, iz kojeg se može vidjeti da je provođenje suzbijanja gripe bilo neobavezno, nesustavno, sporadično i sa sigurnošću neuspješno, zbog nedostatka znanja o gripi. ${ }^{10}$ Preporučeni je lijek bila još jedna u nizu zabluda, a liječnici ga pojedinačnim iskustvom, ako je ono i postojalo, najvjerojatnije znanstveno nisu znali objasniti. lako se govori o lijeku, nema puno riječi o težini same bolesti (vidi prilog 1). Zbog nedostatka znanja o gripi mjere su protiv njena suzbijanja i preporučeni lijekovi u mnogim zemljama svijeta bili vrlo raznoliki. Od široke palete primjenjivanih mjera i uzimanja lijekova do ubrizgavanja eksperimentalnih cjepiva, uspješnim se u prevenciji pokazala jedino karantena, $s$ obzirom na to da je u nekoliko poznatih slučajeva uspjela spriječiti prodor virusa ${ }^{11}$, a u liječenju, oporavak je oboljelih pacijenata $s$ dostupnim toplim obrocima, primjerenim ozračjem i odmorom mogao pridonijeti smanjenju smrtnosti od španjolske gripe ${ }^{12}$.

Članak koji je gotovo desetljeće kasnije, u siječnju 1927. izašao u tjedniku Pučki prijatelj ${ }^{13}$, naslovljen je „Kako da se očuvamo španjolske groznice ili gripe“ i upozorava na moguću ponovnu epidemiju španjolske gripe i piše koje mjere primijeniti ako do njene pojave i dođe. U članku

8 Münchenu.

9 Od 9. kolovoza 1918. list je tiskan ekavicom, čime se izražava težnja za jugoslavenskim jedinstvom u političkom i kulturnom pogledu, gdje je plan o uniformnosti jezika u novoj državi bio izrazito važan. Istodobno, ekavica je u ekspresionističkom razdoblju u Hrvatskoj bila pomodna; razni su je književnici koristili za svoj umjetnički izričaj (Samardžija 2004: 165-166). Mate Balota još u travnju 1918. koristi u Hrvatskom listu ekavicu (Fonović et al., u tisku).

10 Također, treba uzeti u obzir da novine ne čitaju svi stanovnici Pule, a još manje stanovnici okolnih sela. Mala naklada lista nije mogla jamčiti sustavno čitanje o mjerama protiv gripe, a još manje njihovu primjenu.

11 Primjerice, zbog dobro organizirane karantene u svim australskim lukama u listopadu 1918. Australija je izbjegla drugi val španjolske gripe; gradić Gunnison u državi Colorado u SAD-u nije bilježio ni jedan slučaj španjolske gripe što je pripisano zabrani silaska putnika na mjesnoj željezničkoj stanici.

12 Prema podacima registra Pokrajinske bolnice u Puli 84,51\% pacijenata s dijagnozom španjolske gripe nakon boravka u bolnici bilježilo je ozdravljenje. Jedini lijek koji su uz odmor, tople obroke i primjereno ozračje mogli dobiti bio je aspirin - koji gripu ne liječi (Milovan Delić: 226).

13 Glasilo hrvatskog katoličkog pokreta u Istri, tiska se u Krku, Pazinu i Trstu od 1899. do 1928., s pauzom od 1922. do 1924. 
je vidljivo da se spoznalo kako bolest vjerojatno ne napada iste ljude ponovno, kako je gripa teška bolest, prenosiva kapljično, poznati su simptomi, no pokušaj obrane protiv nje isti je kao i deset godina ranije: propisuje se ispiranje usta, raskuživanje rublja te općenito raskuživanje prostora (s tripostotnim hidrogen-hiperoksidom, formamintom, anakotom, anginol tabletama i sl.), upotreba pljuvačnica, odvajanje bolesnika u posebnu sobu i izbjegavanje alkohola, $s$ obzirom na to da može narušiti prirodnu obranu organizma. Također, preporučuje se pozvati liječnika da utvrdi stanje bolesti (Pučki prijatelj, 27. 1. 1927: 4). Iz ovih se redaka vidi da je tik do otkrića virusa (1933.), gripa još uvijek bila najvećim dijelom svijetu nepoznanica.

Postoje primjeri da su vlasti ranije pokušavale propisivanjem mjera zaustaviti određene epidemije u Istri. Razlika je postojala u činjenici da novine preporučuju, dok mjere vlasti propisuju. Primjerice, vrlo detaljne upute sadrži odredba za mjere protiv kolere koju je 12. kolovoza 1831. donijelo Provincijsko zdravstveno povjerenstvo u Trstu kao instrukciju pod br. 372/P. S. C. Dvojezično se, na njemačkom i talijanskom, pisalo o simptomima i o sredstvima borbe protiv kolere koja je u nekoliko navrata snažno napala Istru i Puljštinu. Vrlo strogi propisi doneseni su i 17 godina kasnije, 15. kolovoza 1848., kada je Vlada u Beču izdala Pravilnik na 16 tiskanih stranica kojega se moraju pridržavati okružna poglavarstva, područja, mjesne vlasti, župnici, okružni, kotarski i pomoćni liječnici i kirurzi u vrijeme epidemija općenito, a posebno u slučajevima epidemije kolere (Jelinčić 2006: 532).

Krajem rujna, Hrvatski list u članku „Španjolska bolest širi se“ izvješćuje: „U Budimpešti obolilo je 100.000 osoba od španjolske bolesti. Imade i mnogo slučajeva smrti. - Iz Lavova javljaju, da je španjolska bolest zauzela u Galiciji epidemičan karakter. - Polag nekojih vijesti pojavila se u Italiji kuga: 'Italija' govori o epidemiji s mnogim slučajevima smrti“ (HL, 29. 9. 1918: 1), te se - putem usporedbe s kugom - uočava da je drugi val gripe iznimno snažno udario srednju Europu.

Drugi je val pandemije na Puljštini potvrđen u članku od 8. listopada: „Španjolska 'gripa' u Puli“ u kojem se opaža ozbiljan karakter gripe u Puli. List piše: „I u našem se gradu pojavila po drugi put ova bolest. Taj put nije tako nevina. Imade već dosta žrtava. Medju žrtvama nemilosrdne ove bolesti jesu fregatni poručnik Volani iz Siska i linijski kapetan Stahlberger. Linijski je kapetan Stahlberger bio u mornaričkim krugovima veoma poznata i veoma poštovana ličnost a bio je zbog svoje pravednosti i uvidjavnosti omileo i svim podredjenim časnicima a osobito momčadi, za koju se uvijek zauzimao. Da ova bolest zauzme epidemički karakter, biće potrebno, da i naše gradske oblasti poduzmu slične mere, što su se provele u drugim gradovima" (HL, 8. 10. 1918: 2). Spominje se da se gripa drugi put pojavila u gradu, što znači da je prvi val u Puli također bio prisutan, ali nije bio intenzivan kao jesenski. Prvi val španjolske gripe primjetan je u Puli po broju oboljelih zaprimljenih u Pokrajinsku bolnicu i nije poznata niti jedna smrtna žrtva. Drugi val španjolske gripe stigao je u Pulu u rujnu 1918., što je utvrđeno po broju smrtnih žrtava od gripe iz matica i broju oboljelih koji su se liječili u Pokrajinskoj bolnici u Puli; vrhunac će imati u prvoj polovici listopada te će uz opadanje intenziteta trajati do kraja prosinca (Milovan Delić: 179-180).

U broju od 10. listopada nalazi se manji članak pod naslovom „Španjolska bolest u Beču“, koji izvješćuje da su se u Beču zbog širenja španjolske bolesti zatvorile sve pučke i srednje škole i da će biti zatvorene do 20. listopada“ (HL, 10. 10. 1918: 2). Ove će mjere iz Beča pratiti i puljske vlasti, s obzirom na to da će u nekoliko idućih brojeva izvještavati o zatvaranju škola u Istri, kao i produžavanju prvotnog plana njihova ponovna otvaranja. ${ }^{14} \mathrm{U}$ objašnjenju zašto bi škole trebalo zatvoriti, u jednom članku stoji: „Širi se ko požar, što zahvati, ono i drži. U

14 Članci će biti tiskani pod nazivima: „Zatvaranje škola“ (HL, 12. 10. 1918: 3); „Škole zatvorene do 27. oktobra“ (HL, 19. 10. 1918: 2); "Cr. kr. Hrvatska gimnazija i ženska učiteljska škola u Pazinu“ (HL, 21. 10. 1918: 2); „Produljenje školskih praznika“ (HL, 27. 10. 1918: 2); „Iz Pazina“ (HL, 28. 10. 1918: 2); „Hrvatska gimnazija i ženska učiteljska škola u Pazinu“ (HL, 1. 11. 1918: 2). 
nekim kućama je sva čeljad bolesna" (HL, 28. 10. 1918: 2), ${ }^{15}$ čime se zorno prikazuju značajke španjolske gripe: brzina njene zaraznosti, jačina virusa te neizbježna posljedica nedostatka znanja o karanteni, koja bi u uglavnom siromašnim obiteljima istarskoga poluotoka sa skromnim stambenim standardom ionako bila teško izvediva. Nakon što gripa u prosincu jenjava, list ne piše o ponovnom otvaranju škola; uzrok je vjerojatno reorganizacija školstva u novoj državi i ponovni upis djece. ${ }^{16}$

Sredinom listopada objavljen je poduži članak pod naslovom „Španjolska hunjavica“, u kojem se upozorava na izrazitu zaraznost bolesti i preporučuje mirovanje, s obzirom na to da su primjetni komplicirani slučajevi s upalom pluća koji „...postanu vrlo teški, dapače katkod i smrtni“. Preporučuje se osamljivanje, izbjegavanje doticaja s bolesnim i ukoliko je bolest već nastupila ili se u to sumnja (ako je nastupila ,ježnja ili ognjica“), mirovanje kod kuće (HL, 15. 10. 1918: 2). Ovaj će članak pokazati da se sredinom listopada primjećuje da je bolest teža no što se pretpostavljalo i da ima mnogo smrtnih žrtava od same gripe ili njenih komplikacija.

U broju od 23. listopada nalazi se kratki obavijesni članak da španjolska "hunjavica“ u Beču popušta. Nakon toga članci koji spominju španjolsku gripu govore uglavnom o spomenutom zatvaranju škola ili su oblika osmrtnice osoba stradalih od nje. Primjerice, u rubrici „Domaće vijesti“ objavljena je osmrtnica dvadesetjednogodišnje Milke Grubišić, kćerke "domoljubne obitelji Grubišić", u kojoj se ona romantično opisuje kao „vatrena rodoljupka koja je svojim djelima zadužila grad“ (HL, 25. 10. 1918: 2). Kod osmrtnice učitelja Josipa Zornade iz Roča gripi je pridodan pridjev „,nesretna“ i prozvan je njen karakter uzimanja mladoga stanovništva: „....kao da hoće da su njene žrtve mladi ljudi ili oni u muževnoj dobi, koji u mnogim slučajevima ostavljaju za sobom neopskrbljenu djecu. (...) Neizreciva nas tuga hvata, kad vidimo, kako nam umiru mladi ljudi upravo sada, kad je našem narodu na domaku lepša budućnost“ (HL, 29. 10. 1918: 2).

U broju od 11. prosinca u rubrici „Dopisi iz Istre“ stoji sjećanje na dvije žrtve španjolske gripe koje su bile pokopane 5. prosinca, sudskog činovnika Ivana Filiplića i učenice 4. razreda hrvatske gimnazije, Marije Dušan. Za Ivana se spominje da je bio mlad, najljepših sposobnosti i da je iza sebe ostavio mladu udovicu, a kod Marije se naglašavanju njene adolescentske godine (HL, 11. 12. 1918: 1). Među osmrtnicama u Hrvatskom listu ima i onih koje spominju osobe umrle nakon kratke i teške bolesti, ali možemo pretpostaviti, isto kao što i Hutinec u svom članku naglašava kod primjera središnje Hrvatske, da se ta bolest vjerojatno odnosi na španjolsku gripu, koja doista može stajati s tim atributima. Sporadični članci o španjolskoj gripi u Hrvatskom listu tijekom prosinca sve su rjeđi, po svoj prilici kao posljedica povlačenja pandemije, no i zbog zasjenjivanja vijestima o važnim političkim događajima za Hrvate u Istri, u kojima se očituje entuzijazam Puljana zbog mogućeg ulaska u novu slavensku državu, ali i tjeskoba zbog novonastale situacije s talijanskom vlašću.

Po broju i kvaliteti članaka koji spominju španjolsku gripu u Hrvatskom listu možemo zaključiti da je ona vrlo malo i izrazito površno zastupljena. Pojava španjolske gripe i njezin tijek i u ostalom su hrvatskom tisku također nedovoljno zastupljeni. Dnevnici Hrvatska riječ i Obzor, koji su gripu pratili od kraja svibnja, na početku su se bavili gripom „...najčešće na senzacionalističkoj razini. Ona se smatrala neugodnom, ponekad smrtonosnom bolešću, no nije bilo nikakvih naznaka panike ili poduzimanja opsežnih mjera zaštite od njenog širenja" (Hutinec 2006: 230). Mediji su vjerojatno samo oslikavali službeni pristup države toj temi; Fatović-Ferenčić i Šain u svome članku tvrde da su organizirane reakcije države

15 O zatvaranju škola u Istri pod navalom drugoga pandemijskog vala u listopadu 1918. piše i Marcelo Bogneri u svojim kronikama: izvještava da je 11. listopada objavljen javni proglas o zatvaranju škola do 19. listopada, a javnim proglasom 19. listopada produžena ta odluka za tjedan dana (Bogneri 1990: 28).

16 U prosincu se otvaraju četiri hrvatske škole u Puli, a u planu je i peta; članci s tom tematikom u Hrvatskom listu pozivaju čitateljstvo neka svoju djecu ondje upišu. 
izostale sve do kraja kolovoza, kad su tek lokalne vlasti počele izdavati proglase o načinima sprječavanja zaraze i strože propise o prijavljivanju zaraženih osoba (Fatović-Ferenčić et al. 1991: 446). Kotarske su oblasti i gradska poglavarstva u središnjoj Hrvatskoj trebala izvijestiti o mortalitetu od gripe ili njezinih komplikacija za rujan i svakog 10. u mjesecu, no ova će inicijativa - iako će povjereništvo za zdravstvo Narodnog Vijeća Slovenaca, Hrvata i Srba zahtjev nekoliko puta ponavljati - biti neuspješna zbog sve lošije prometne povezanosti zemlje prouzročene slomom Austro-Ugarske Monarhije i akcijama zelenog kadra te tromosti činovničkog aparata (Hutinec 2006: 232). Za ovakvu djelatnost na području Puljštine i Istre kao dijela Austrijskoga primorja za sad nema podataka, ali se zbog „preporuka“ ponašanja u slučaju gripe koje se dvaput u Hrvatskom listu javljaju može pretpostaviti da su stroži državni propisi poput propisanih mjera protiv pandemije (poput spomenutih mjera protiv kolere stotinjak godina ranije) te sustavno prijavljivanje morbiditeta i mortaliteta vjerojatno izostali.

\section{Zaključak}

O španjolskoj se gripi u Hrvatskom listu izvještavalo, no s obzirom na njenu virulentnost, veliki morbiditet i mortalitet, kao i socijalne posljedice koje je prouzročila, ona je dobila iznimno mali medijski prostor.

Hrvatski list donosi sporadične članke o španjolskoj gripi u lipnju i početkom srpnja te se odnosi prema njoj samo kao prema senzaciji. $U$ drugoj polovici rujna, shvaća se ozbiljnost pandemije, no jedini objavljeni zdravstveni „recept“ protiv bolesti prepisan je iz drugog europskog lista, a nekoliko dobronamjernih zdravstvenih savjeta objavljeni su kao rezultat subjektivne interpretacije o etiologiji bolesti i nisu obimom i raznovrsnošću parirali zdravstvenim odgovorima protiv gripe u drugim dijelovima svijeta - u pitanju je bilo nekoliko nedjelotvornih mjera, nedostatak kvalitetnih savjeta i nedostatna objašnjenja profilakse.

Početak će se vrhunca drugoga vala španjolske gripe na Puljštini zbiti početkom listopada i u dnevniku će se ta pojava opisati usporedbom nove gripe s kugom, čime se prikazao intenzitet i težina nove pošasti u drugom, izrazito smrtonosnom valu. Uočava se da gripa u ovom javljanju pogađa mlado stanovništvo, što je također posebnost španjolske gripe. Spominje se da je gripa u listopadu drugi put pogodila Pulu, čime se potvrđuje i postojanje prvoga, ne toliko jakoga vala. No bez obzira na trajanje i intenzitet pandemije u južnoistarskome selu i gradu, vijesti će o njoj u Hrvatskom listu nakon proglašenja kraja rata biti sve kraće i rjeđe; tema španjolske gripe u novinskim će člancima među onima o nesigurnoj novoj političkoj situaciji postati periferna vijest, uz nezaobilazan dojam da se novinari žele otresti glasa o njoj kao što bi se željeli otresti same bolesti.

Razlozi zbog kojih je španjolska gripa u Hrvatskom listu dobila mjesto na margini mogu se svrstati u političke, socijalne i mentalne. Prvi su uzrokovali zasjenjenost pojave vijestima o posljednjim operacijama Prvoga svjetskog rata i kratkotrajnom euforijom stanovništva zbog nade o pripojenju Istre Državi SHS uslijed raspada Austro-Ugarske Monarhije, a kasnijim korjenitim promjenama po dolasku talijanske vojske nakon sedmodnevne vladavine Narodnih vijeća; zbog socijalnih su razloga u prvi plan stavljane vijesti o aprovizaciji, dijeljenju milodara za samohrane roditelje, načinima rješenja problema povrata „evakuiraca“ i sl., koje su ukazivale na bijedu ratne i poratne svakodnevice i teško preživljavanje tamošnjeg stanovništva. U takvoj političkoj i socijalnoj situaciji pretpostavlja se da bolest, koja ujedno i slabi, ima manji značaj. Posljednje, ali ne i manje važno; nakon iščitanih članaka u Hrvatskom listu nameće se zaključak da je španjolska gripa shvaćena samo kao jedna u nizu pošasti koje su pogodile južnu Istru i Pulu, pa je kao još jedna prepreka životu trebala biti što prije zaboravljena - čime se na primjeru južne Istre može potvrditi Crosbyjev „mentalitet zaborava“. Svi će ovi razlozi utjecati na kasnije zanemarivanje španjolske gripe u kolektivnom sjećanju i historiografiji. 
Prilog 1: Prva u rubrici „Dnevne vesti“ vijest je o liječenju španjolske gripe (HL, 20. 9. 1918: 2).

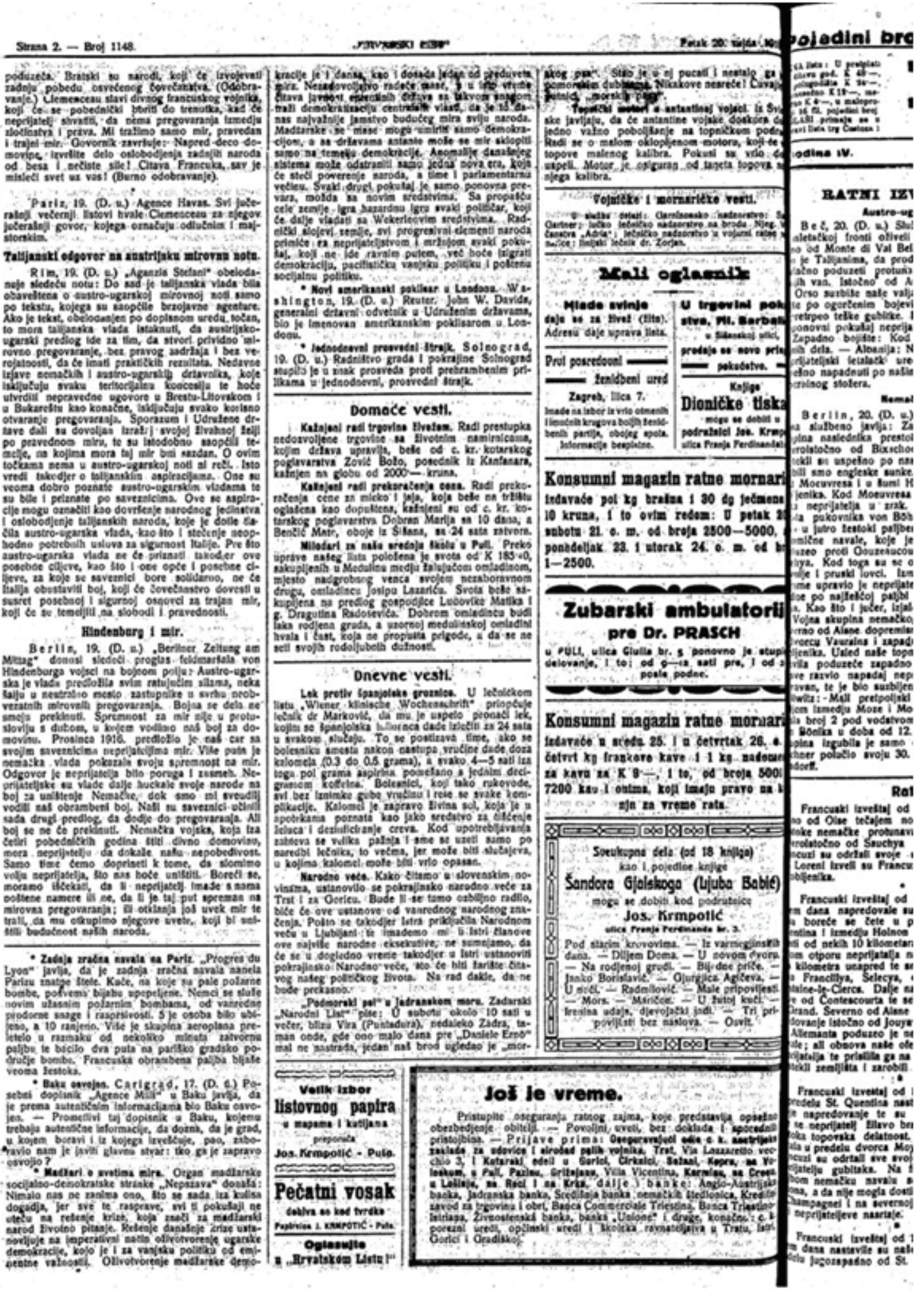




\section{POPIS IZVORA}

Hrvatski list, Pula, 1. svibnja 1918. - 18. prosinca 1918.

Pučki prijatelj, Trst, 27. siječnja 1927.

\section{POPIS LITERATURE}

\section{BERTOŠA 2002}

Miroslav Bertoša, Izazovi povijesnog zanata: Lokalna povijest i sveopći modeli, Zagreb 2002.

\section{BOGNERI 1990}

Marcello Bogneri, Chronache di Pola e dell'Istria: 1915-1938, La guerra, la redenzione e l'unione alla Madrepatria, Trieste 1990.

\section{CROSBY 2003}

Alfred W. Crosby, America's Forgotten Pandemic: The Influenza of 1918, Cambridge 2003.

\section{DUDA 2010}

Igor Duda, Pronađeno blagostanje: Svakodnevni život i potrošačka kultura u Hrvatskoj 1970ih i 1980-ih, Zagreb 2010.

\section{FATOVIĆ-FERENČIĆ ET AL. 1991}

Stella Fatović-Ferenčić, Snježana Šain, „Španjolska gripa kao uzrok smrti u gradu Zagrebu 1918. godine“, Liječnički vjesnik, 113., 1991., 444-446.

\section{FONOVIĆ ET AL.}

Teodora Fonović, Vanessa Vitković, „Hrvatski jezik u Hrvatskome listu“, Riječki filološki dani, 9 (u tisku).

\section{HUTINEC 2006}

Goran Hutinec, „Odjeci epidemije španjolske gripe 1918. u hrvatskoj javnosti", Radovi Zavoda za hrvatsku povijest, 38., 2006., 227-242.

\section{JELINČIĆ 2006}

Jakov Jelinčić, „Matične knjige umrlih - važan izvor za povijest zdravstva (primjer matičnih knjiga umrlih župe Vodnjan od 1815. do 1893.)“, u: Marino Manin et al. (ur.), Identitet Istre - Ishodišta i perspektive, Zbornik Instituta društvenih znanosti Ivo Pilar, knjiga 26., Zagreb 2006.

\section{JOHNSON ET AL. 2002}

Johnson NP, Mueller J., „Updating the accounts: global mortality of the 1918-1920 "Spanish" influenza pandemic", Bull Hist Med, 2002., 76:105-15.

\section{KOLATA 1999}

Gina Kolata, Flu: The Story of the Great Influenza Pandemic of 1918 and the Search for the Virus that caused it, New York 1999.

\section{MILOVAN DELIĆ 2013}

Iva Milovan Delić, Španjolska gripa 1918. - 1919. u gradu Puli - socijalni aspekti mortaliteta od španjolske gripe i urbana anatomija pandemije, obranjena doktorska disertacija na Filozofskom fakultetu u Zagrebu, veljača 2013.

\section{MOXNESS ET AL. 2008}

John F. Moxnes - Olav Albert Christophsersen, "The Spanish flu as the worst case scenario", Microbial Ecology in Health and Disease, Vol. 20, No 1(2008), str. 1-27.

\section{NOVAK 2005}

Božidar Novak, Hrvatsko novinarstvo u 20. stoljeću, Zagreb 2005.

\section{PHILLIPS ET AL. 2003}

Howard Phillips - David Killingray (ur.), The Spanish Influenza Pandemic of 1918-1919: New Perspectives, London - New York 2003.

\section{ROSENBERG 1992}

Charles E. Rosenberg, Explaining Epidemics and Othes Studies in the History of Medicine, Cambridge 1992.

\section{SAMARDŽIJA 2004}

Marko Samardžija, Iz triju stoljeća hrvatskoga standardnog jezika, Zagreb 2004. 


\section{SAŽETAK}

Pandemija španjolske gripe 1918.-1919. koja je na svom putu u tri susljedna vala uzela oko 50-100 milijuna žrtava tek je nekoliko posljednjih desetljeća dobila pažnju povjesničara. U tom poletu proučavanja pojave, tijeka i posljedica španjolske gripe vrlo se važna uloga dala tisku kao slici svoga vremena. Jedini dnevni list koji se u Puli u vrijeme pojave španjolske gripe tiskao na hrvatskom jeziku, Hrvatski list, na dvije je stranice ili povremeno četiri stanovnike Puljštine obavještavao o političkim, socijalnim, gospodarskim događajima, zdravstvenim, prosvjetnim i kulturnim prilikama na svjetskoj i lokalnoj razini te in katkad zabavnim štivom didaktičnog karaktera „prosvjećivao“. Sredinom i u drugoj polovici 1918. list izvještava o pojavi i kretanju španjolske gripe, preporučenim „lijekovima“ i mjerama zaštite, javljanju drugoga vala u Puli, zatvaranju škola u Istri zbog moguće zaraze, tipičnog stradavanja mladoga stanovništva od španjolske gripe i ostalo. Ipak, članci su sporadični i malobrojni, a razlog je tome zasjenjenost pandemije sudbinskim političkim događajima s konca rata, socijalnim prilikama u južnoj Istri koje su zahtijevale veći medijski prostor od jedne bolesti, kao i mentalnim razlozima potiskivanja sjećanja na jednu u nizu pošasti koja je zahvatila južnoistarsko stanovništvo.

\section{SUMMARY}

\section{Reports About Spanish Flu in Pula's Daily Hrvatski list}

The pandemic of Spanish flu of 1918-1919, which, in three waves, took 50-100 million lives, became the point of interest of the historians only in the last several decades. In this newly found enthusiasm for the research of the phenomenon, course and consequences of the Spanish flu, a very important role was given to the press as the reflection of the times. The only daily newspapers which were issued in Croatian language in Pula during the Spanish flu, "Hrvatski list", dedicated two or four pages to inform the citizens of Pula about the political, social, economic events, and health, education and cultural news on the international and local level; sometimes, it "enlightened" its readers through the funny texts with didactic notes. In the middle and second half of 1918, the paper reports about the appearance and rates of the Spanish flu, recommended "cures" and measures of protection, appearance of the second wave in Pula, of closing of the schools in Istria because of the possible infection, typical perishing of the young population because of the Spanics flu etc. Nevertheless, the articles are sporadic and few, because the epidemics was overshadowed by the fateful political events at the end of the war, social circumstances in the southern Istria, which required more space than the epidemic, and also the repression of the memory of one of many plagues which tortured the southern Istrian population.

Keywords: Spanish flu, news, Hrvatski list, mortality, morbidity, second wave, "mentality of oblivion" 